\title{
Sistem Akusisi Data Online Proses Sintering dengan Atmosfir Hidrogen untuk Prediksi Parameter Keselamatan
}

\author{
Acquisition Online Data System Sintering Process with Atmosfer \\ Hidrogen for Safety Parameter Prediction
}

\author{
Adhi Mahendra ${ }^{1}$, Dede Sutarya ${ }^{2}$ \\ ${ }^{I}$ Fakultas Teknik Universitas Pancasila, Srengseng Sawah, Jagakarsa, Jakarta \\ ${ }^{2}$ Badan Tenaga Nuklir Nasional, Serpong, Banten \\ Email:johanes70am@yahoo.com
}

\begin{abstract}
Increasing the use and application of hydrogen as a renewable energy source or application in industrial processes, has increased a pressure to ensure the safety handling and that monitoring. The safety issues related to hydrogen gas are further exasperated by expensive instrumentation required to measure the percentage of explosive limits, flow rates and generated pressure. An innovative solution to address the safety issues of hydrogen and costly physical sensor is to use virtual sensors based on neural network which learn from the data to predict the parameters related to the safety of hydrogen. This study aimed to obtain the dataset that describe the entire behavior of the sintering process with a hydrogen atmosphere. This research developed a data acquisition system for the sintering process and testing using real sintering process to obtain the necessary data. The results of experiments on the data acquisition system for online data acquisition to measure process variables showed a good performance. The obtained data can be described from the overall behavior of hydrogen in the sintering process. Thus these data can be used as a dataset for modeling neural networks in predicting the safety parameters of hydrogen in future studies.
\end{abstract}

Keywords: data acquisition system, process variable, hydrogen safety, sintering furnace

\begin{abstract}
Abstrak
Meningkatnya penggunaan dan penerapan hidrogen sebagai sumber energi terbarukan atau aplikasi pada proses industri, telah meningkatkan tekanan untuk memastikan penanganan keselamatan serta pemantauannya. Masalah keselamatan yang berkaitan dengan gas hidrogen lebih jauh dihambat oleh mahalnya instrumentasi yang diperlukan untuk mengukur persentase batas ledakan, laju aliran dan tekanan yang dihasilkan. Solusi inovatif untuk mengatasi isuisu keselamatan hidrogen dan sensor fisik yang mahal adalah dengan menggunakan sensor virtual berdasarkan jaringan syaraf tiruan yang belajar dari data untuk memprediksi parameter yang berkaitan dengan keselamatan hidrogen. Penelitian ini bertujuan untuk mendapatkan dataset yang menggambarkan seluruh perilaku proses sintering dengan atmosfir hidrogen. Dalam penelitian ini dikembangkan sebuah sistem akuisisi data untuk proses sintering serta mengujinya pada proses sintering sebenarnya untuk mendapatkan data yang diperlukan. Hasil percobaan pada sistem akuisisi data secara online untuk mengukur variabel proses menunjukkan kinerja sistem yang baik. Data yang diperoleh dapat menggambarkan perilaku keseluruhan hidrogen dalam proses sintering. Dengan demikian data ini dapat digunakan sebagai dataset untuk pemodelan jaringan saraf tiruan dalam memprediksi parameter keselamatan hidrogen dalam studi berikutnya.
\end{abstract}

Kata kunci: sistem akuisisi data, variabel proses, keselamatan hidrogen, tungku sintering

\section{Pendahuluan}

Riset tentang hidrogen sebagai sumber energi masa depan terus meningkat, terutama dalam hubungannya dengan sumber energi terbarukan. Sebagai media penyimpanan energi, hidrogen memenuhi beberapa persyaratan secara

Received: 1 Maret 2015; Revised: 30 Maret 2015; Accepted: 4 Mei 2015 ; Published online: 10 Juli 2015

C2015 INKOM 2015/15-NO413 bersamaan, terbukti merupakan pembawa energi paling ramah lingkungan karena "gas buang" yang dilepaskan ketika menggunakan hidrogen hanya uap air. Selain daripada itu, hidrogen memiliki karakteristik khusus yang membuat media tersebut ideal untuk pembangkit listrik dari sumber energi terbarukan yang benar-benar bebas emisi dari awal sampai akhir. Tidak seperti bahan bakar fosil seperti minyak mentah atau gas alam, hidrogen tidak akan pernah habis, karena hidrogen adalah unsur yang paling umum 
ditemukan di alam. [1]. Selain itu, hidrogen dapat disimpan dan digunakan baik untuk menghasilkan listrik langsung atau sebagai bahan bakar, yang membuatnya sangat tepat untuk aplikasi stasioner maupun bergerak. Namun, harus diingat bahwa itu hanya media untuk penyimpanan dan bukan sumber energi dengan sendirinya, karena harus diperoleh dari air atau hidrokarbon melalui proses pemisahan.

Selain itu, aplikasi hidrogen dalam sektor energi, terutama untuk kendaraan dan penggunaan rumah tangga merupakan prospek yang menjanjikan yang menuju pada peningkatan penggunaan teknologi hidrogen. Hidrogen yang digunakan dalam sel bahan bakar atau sebagai bahan bakar pada motor bakar (internal combustion engine) akan mendorong semakin berkurangnya polusi. [2]. Perkembangan yang cepat teknologi aplikasi hidrogen dalam waktu dekat untuk digunakan sebagai pembawa energi dan bahan bakar, hanya memungkinkan jika risiko terjadinya kecelakaan pada sisi produksi, selama penyimpanan, transportasi, atau pengguna akhir dapat dikendalikan untuk menghindari peningkatan risiko kepada publik. Oleh karena itu sensor keselamatan hidrogen merupakan hal yang sangat penting untuk menjamin implementasi yang aman dari sistem hidrogen. Namun mahalnya sensor fisik atau membangun sistem eksperimen untuk aplikasi hidrogen tertentu masih menjadi hambatan. [3] [4].

Solusi yang dapat dilakukan untuk mengatasi masalah keselamatan hidrogen dan mahalnya membangun sistem sensor fisik atau membangun fasilitas eksperimen tertentu adalah dengan menggunakan sensor virtual berbasis jaringan saraf tiruan untuk memprediksi parameterparameter yang berkaitan dengan keselamatan hidrogen. Dengan melakukan prediksi parameter keselamatan maka kecelakaan dapat diantisipasi lebih awal sehingga kerusakan parah ataupun korban jiwa yang mungkin terjadi sebagai akibat kecelakaan tersebut dapat dihindari. [5]

Untuk memperoleh hasil prediksi yang valid diperlukan data yang cukup yang menggambarkan seluruh perilaku parameter yang berpengaruh terhadap keselamatan hidrogen. Oleh karena itu diperlukan sebuah sistem akusisi data yang memadai yang mengukur semua parameter yang dibutuhkan.

Paper ini bertujuan untuk mendisain sebuah sistem akusisi data yang sesuai untuk mengukur parameter yang dibutuhkan dalam prediksi keselamatan hidrogen. [6]

\section{Metode Penelitian Dan Material}

Salah satu kecenderungan dalam pengembangan teknologi pengukuran adalah pengembangan sistem pengukuran. Pada sistem pengukuran, perangkat keras (sensor dan tranduser) serta perangkat lunak untuk pengolahan data, disusun sedemikian rupa untuk dapat, mengirimkan, memproses dan menampilkan serta menyimpan data hasil pengukuran. Sistem pengukuran ini dilengkapi dengan PC atau chip mikroprosesor yang bertugas untuk mengendalikan arus informasi di sistem, untuk memproses data pengukuran, dan kadang-kadang untuk menyimpannya. Komputer atau chip mikroprosesor adalah kontroler sistem, yaitu perangkat pengelolaan sistem. Pengukuran sistem dengan komputer (PC), yang dikenal sebagai "sistem pengukuran berbasis komputer", adalah sangat penting, mengingat semakin meluasnya penggunaan PC di bidang pengukuran industri dan penelitian laboratorium.

Sistem pengukuran yang dirancang untuk mengukur kuantitas fisik berbagai obyek pada sistem pengukuran berbasis komputer terdiri dari komponen fungsional berikut:

- Sensor dan Transducer. Sensor ini mengubah parameter listrik sebagai fungsi dari nilai kuantitas yang diukur (misalnya, perubahan hambatan dalam fungsi temperatur), sedangkan Tranduser mengubah parameter listrik dari sensor menjadi tegangan langsung atau arus searah (misalnya, tegangan listrik pada output).

- Pengkondisian sinyal atau sirkuit standardisasi level sinyal dari pengukuran transduser ke kisaran tegangan input dari konverter analog-ke-digital.

- Konverter Analog-ke-digital (ADC) atau alat ukur digital yang mengandung konverter, tugas ADC adalah untuk mengkonversi analog menjadi sinyal digital.

- Perangkat untuk tampilan visual, perangkat ini akan menampilkan hasil pengukuran dalam bentuk tampilan digital, layar instrumen digital (misalnya, osiloskop digital), atau monitor komputer.

- Sebuah komputer dengan perangkat lunak dan memori yang memadai.

- Aktuator atau generator sinyal uji.

Rancangan sistem data akuisis menggunakan PC diperlihatkan pada Gambar 1. 


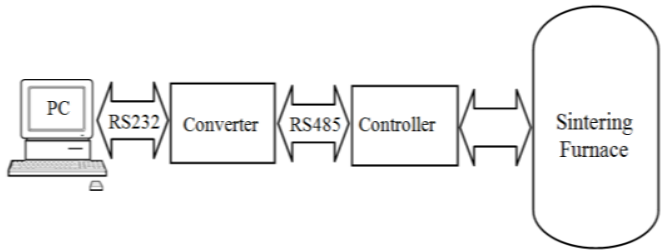

Gambar 1. Sistem akusisi data furnace

\section{Hasil Disain Daq Dan Proses}

Untuk mendapatkan data masukan ke sensor virtual seperti yang diperlihatkan pada Gambar 2, maka pada tungku sinter perlu di tambahkan sensor-sensor untuk mengukur parameter proses yang kemudian di akuisisi oleh sebuah modul DAQ. Data yang diperoleh kemudian diolah menjadi database untuk model sensor virtual. Selanjutnya database tersebut akan digunakan sebagai bahan untuk memahami atau memodelkan prilaku sistem (learning) dalam memprediksi parameter keselamatan proses sintering.

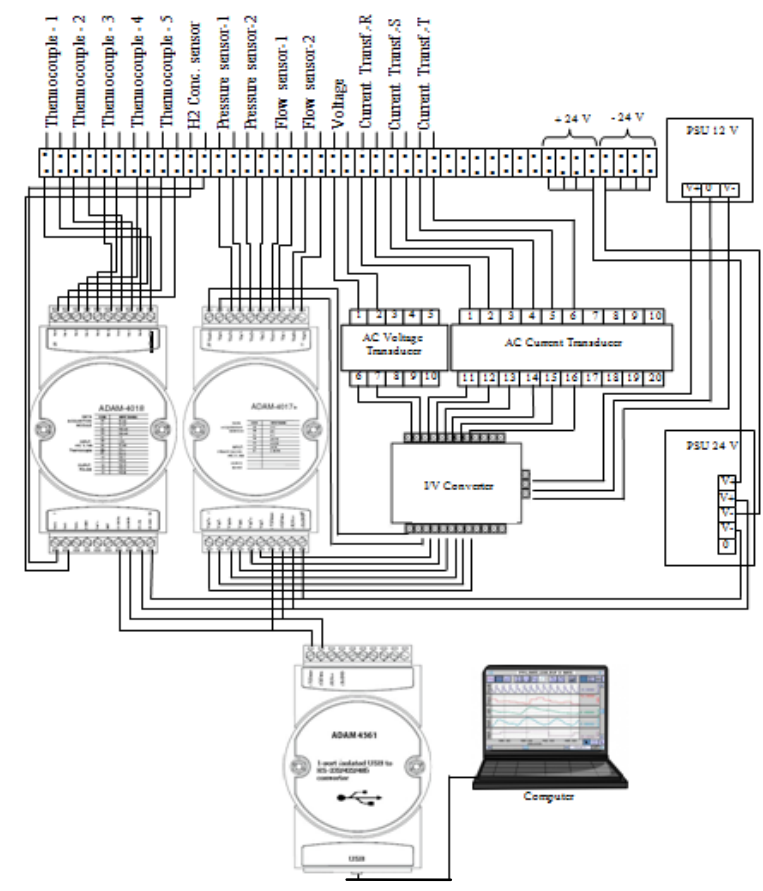

Gambar 2 Disain sistem skusisi data

\subsection{Sensor dan Tranduser}

Sensor dan transduser yang digunakan untuk mengukur parameter proses sintering yang yang digunakan pada sistem akuisisi data adalah sebagai berikut.

a. Sensor Temperature

Sensor temperatur yang digunakan pada sistem data akusisi yang di rancang pada tungku sinter menggunakan Termokopel. Termokopel dibuat dari dua logam berbeda yang terhubung pada ujungnya dengan las, solder, atau dipilin. Pada titik sambungan yang terbuat dari dua logam berbeda atau paduan logam, akan timbul beda potensial.

Thermocouple yang digunakan sebagai sensor temperature pada tungku sinter diperlihatkan pada Tabel 1.

b. Sensor Aliran Gas

Sensor aliran gas (flow) yang digunakan adalah jenis laminar flow meter. Laju aliran ditentukan dengan mengukur penurunan tekanan pada batasan internal yang unik, dikenal sebagai Elemen Laminar Flow (LFE). Pembatasan ini dirancang sedemikian rupa sehingga molekul gas dipaksa bergerak di jalur paralel sepanjang seluruh panjang bagian untuk seluruh rentang operasi perangkat. Tidak seperti perangkat pengukuran aliran dengan tekanan, hubungan antara penurunan tekanan dan aliran linear pada flowmeter laminar. Gambar 4 dan 5 memperlihatkan prinsip kerja sensor laminar dan sensor yang digunakan.

Tabel 1: Thermocouple sebagai Sensor Temperature yang Digunakan

\begin{tabular}{|c|c|c|c|c|c|c|}
\hline $\begin{array}{l}\text { Typ } \\
\text { e }\end{array}$ & $\begin{array}{l}\text { Metal } \\
(+)\end{array}$ & $\begin{array}{l}\text { Metal(- } \\
\text { - }\end{array}$ & $\begin{array}{l}\mathbf{k T} \\
\left(\mu \mathrm{V} /{ }^{\circ}\right. \\
\mathrm{C})\end{array}$ & $\begin{array}{l}\text { Range } \\
\left({ }^{\circ} \mathrm{C}\right)\end{array}$ & $\begin{array}{l}\text { Toleranc } \\
\text { e } \Delta \mathbf{T} \\
\left(\mathbf{7 5 0} 0^{\circ} \mathbf{C}\right)\end{array}$ & $\begin{array}{l}\text { Properti } \\
\text { es }\end{array}$ \\
\hline K & $\begin{array}{l}\text { Chro } \\
\text { mel } \\
\text { Ni-Cr }\end{array}$ & Nickel & 0.5 & $\begin{array}{l}-270 \text { to } \\
+1,370\end{array}$ & $\begin{array}{l}\text { Class 1: } \\
\pm 3.0^{\circ} \mathrm{C} \\
\text { Class 2: } \\
\pm 5.6^{\circ} \mathrm{C}\end{array}$ & $\begin{array}{l}\text { Good } \\
\text { linearity }\end{array}$ \\
\hline W3 & $\begin{array}{l}\text { W- } \\
\text { Re3 } \\
97 \% \\
\text { W+3 } \\
\% \mathrm{R}\end{array}$ & $\begin{array}{l}\text { W- } \\
\text { Re25: } \\
75 \% \text { W+ } \\
25 \% \operatorname{Re}\end{array}$ & 18 & $\begin{array}{l}0 \text { to } \\
+2,320\end{array}$ & $\begin{array}{l}\text { No class } \\
1 \\
\text { class 2: } \\
\square 10 \square \mathrm{C}\end{array}$ & $\begin{array}{l}\text { High } \\
\text { operation } \\
\text { temperat } \\
\text { ure }\end{array}$ \\
\hline
\end{tabular}

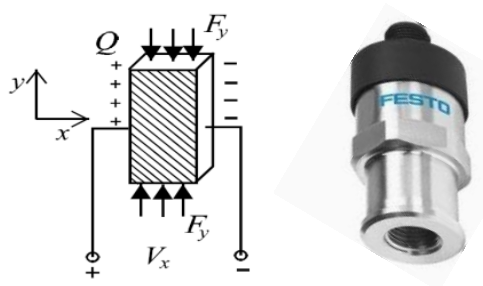

Gambar 3. Prinsip Kerja Pressure Transmitter Piezoelektrik FESTO

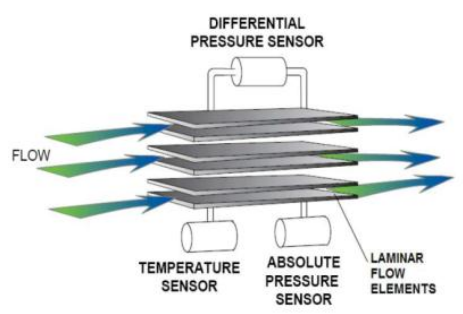

Gambar 4. Prinsip Kerja Flow Sensor Laminar
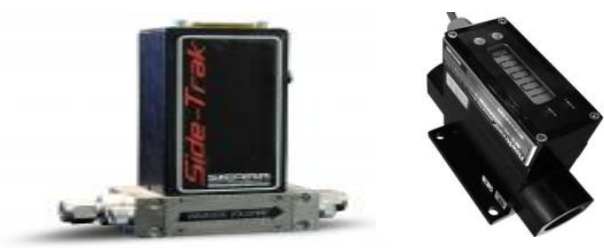

Gambar 5. Flow Sensor yang Digunakan 
c. Sensor Konsentrasi Gas H2

Elemen sensor gas Figaro adalah semikonduktor timah dioksida $(\mathrm{SnO} 2)$ yang memiliki konduktivitas rendah di udara bersih. Keberadaan gas akan terdeteksi, dimana kenaikan konduktivitas sensor tergantung pada konsentrasi gas di udara. Sebuah rangkaian listrik sederhana digunakan untuk dapat mengkonversi perubahan konduktivitas ke sinyal output yang sesuai dengan konsentrasi gas. Sensor Figaro TGS 813 diperlihatkan pada Gambar 6.
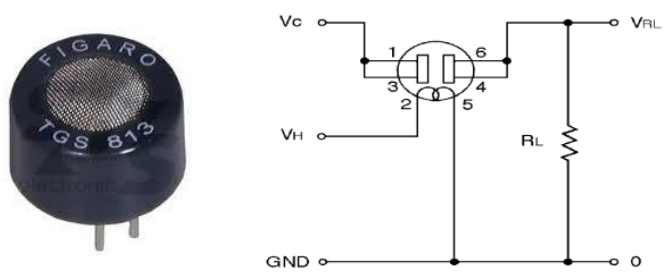

Gambar 6. Sensor Konsentrasi Gas H2 di Udara Figaro TGS813

d. Sensor \& Tranduser Arus Heater

Sensor arus AC yang dipergunakan pada sistem akusisi data adalah sensor efek hall yang dapat mengukur medan magnet disekitar kawat berarus. Sensor arus dengan prinsip efek hall dapat mengukur arus dengan sangat tepat. Di samping itu sensor medan magnet ini dapat dimanfaatkan dalam banyak keperluan, karena medan magnet dapat direspon dalam range frekuensi yang cukup besar.

Trafo arus mengukur arus $0-1050 \mathrm{~A}$ dengan keluaran arus $0-5 \mathrm{~A}$, selanjutnya keluaran dari trafo arus digunakan oleh transducer arus yang memberikan keluaran standar untuk instrumentasi $4-20 \mathrm{~mA}$, seperti yang di perlihatkan pada Gambar 7.

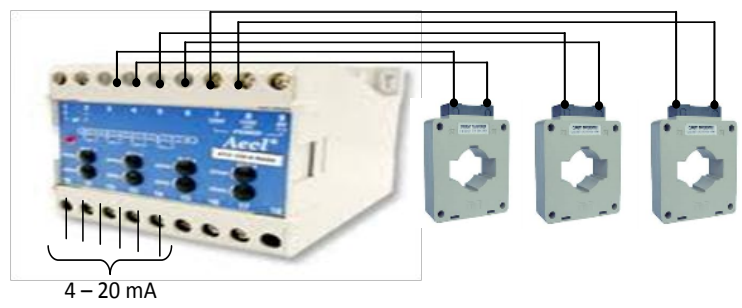

Gambar 7. Sensor dan Tranduser untuk Arus Heater

\subsection{Modul Input Analog dan Konverter Komunikasi ADAM Series}

ADAM series merupakan sebuah modul antarmuka yang didalamnya terkandung sebuah mikroprosesor. ADAM Series dapat dikontrol secara remote melalui sebuah perintah dengan manggunakan format ASCII dan ditransmisikan melalui protokol RS-485. ADAM series mencakup pengkondisian sinyal, isolasi, $\mathrm{A} / \mathrm{D}$ atau D/A converter, pembanding data dan fungsi komunikasi digital.

ADAM 4000 series didesain untuk keperluan industri yang menggunakan catu daya $24 \mathrm{Vdc}$ dan dapat menerima daya dari supply sekitar +10 sampai $+30 \mathrm{Vdc}$. Modul ADAM yang di gunakan pada sistem akusisi data proses sintering adalah ADAM-4017+, ADAM-4018 dan ADAM-4561. Ketiga modul ADAM yang digunakan akan dijelaskan secara singkat pada bagian berikutnya.

a. Modul Input Analog ADAM-4017 dan 4018. ADAM-4017/4018 adalah modul input analog 16-bit, 8-kanal input yang menyediakan rentang masukan yang dapat diprogram pada semua kanal. Modul ini merupakan solusi hemat untuk pengukuran industri dan aplikasi monitoring. Modul ini juga menyediakan pengkondisian sinyal, konversi A/D, dan fungsi komunikasi digital RS-485
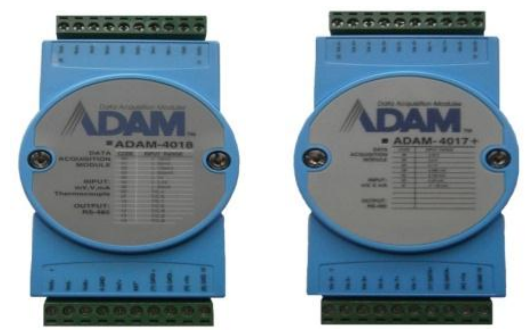

Gambar 8. Modul ADAM-4017+ dan ADAM4018

ADAM-4017/4018 menggunakan mikroprosesor 16-bit yang mengendalikan konverter $\mathrm{A} / \mathrm{D}$ untuk mengubah tegangan atau arus dari sensor menjadi data digital. Data digital tersebut kemudian diterjemahkan ke dalam unit teknik. Bila diminta oleh komputer host, modul mengirimkan data ke host melalui antarmuka RS-485 standar. Spesifikasi ringkas kedua modul adalah sebagai berikut:

- RS-485 (2-kabel) ke host

- Kecepatan: 1200, 2400, 4800, 9600, 19200, $38400,57600,115200$ bps

- Jaram maksimum komunikasi: 4000 feet (1.2 $\mathrm{km})$

- Pemasangan dan pelepasan modul secara online.

- Daya +10 +30 VDC

- Perlindungan terhadap tegangan balik 
- Temperature operasi $-10 \sim 70^{\circ} \mathrm{C}(14 \sim$ $\left.158^{\circ} \mathrm{F}\right)$

- Kelembaban 5 95\%, tanpa-kondensasi.

b. ADAM-4561 Konverter RS-422/485 ke USB Advantech ADAM-4561 memungkinkan pengguna PC untuk menghubungkan perangkat serial menggunakan antarmuka USB. Dengan ADAM-4561, pengguna langsung mendapatkan satu tambahan port RS-232/422/485 kecepatan tinggi. Selain itu, karena catu daya berasal dari port USB, maka tidak diperlukan adaptor daya tambahan. Spesifikasi ADAM-4561:

- Antarmuka jaringan: USB

- Serial: 3-kabel RS-232, RS-422, RS-485

- Kecepatan transmisi: 75 bps hingga 115.2 Kbps

- Proteksi isolasi: 3,000 V

- Driver : Windows 98/ME/2000/XP

- Jarak maksimum: $15 \mathrm{ft}(4.6 \mathrm{~m})$

- Pemasangan: DIN-rail, panel mounting.

- Temperatur operasi: 0 to $70^{\circ} \mathrm{C}$

- Kelembaban: 20\% to 95\% (tanpa-kondensasi)

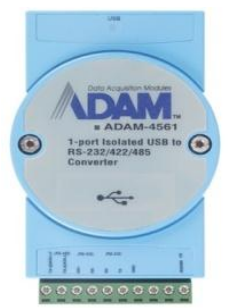

Gambar 9. Modul ADAM 4561 RS-422/485 USB Converter

Sensor dan tranduser, modul data akusisi yang di gunakan dan batasan parameter masing-masing sensor pada sistem untuk mengakuisisi data pada proses sintering di perlihatkan pada Tabel 2 .

\begin{tabular}{|c|c|c|c|c|c|c|}
\hline \multirow[b]{2}{*}{$\begin{array}{l}\mathrm{N} \\
\mathrm{o}\end{array}$} & \multirow{2}{*}{$\begin{array}{l}\text { INPUT } \\
\text { PARA } \\
\text { METER }\end{array}$} & \multirow[b]{2}{*}{ SENSOR } & \multirow[b]{2}{*}{ KET. } & \multicolumn{2}{|c|}{ DAQ MODUL } & \multirow[b]{2}{*}{$\begin{array}{l}\text { SUPPL } \\
\text { Y }\end{array}$} \\
\hline & & & & TIPE & $\begin{array}{l}\text { CHA } \\
\text { NNEL } \\
\end{array}$ & \\
\hline 1 & $\begin{array}{l}\text { Temper } \\
\text { atur } \\
\text { (Tc1) }\end{array}$ & $\begin{array}{l}\text { Thermocouple } \\
\text { (W3Re25) }\end{array}$ & $\begin{array}{l}\text { Temp.Tungku } \\
\text { Sinter }\end{array}$ & $\begin{array}{l}\text { mv Adam } \\
4018\end{array}$ & Ch 00 & - \\
\hline 2 & $\begin{array}{l}\text { Temper } \\
\text { atur } \\
(\mathrm{Tc} 2)\end{array}$ & $\begin{array}{l}\text { Thermocouple } \\
\text { (Tipe-K) }\end{array}$ & $\begin{array}{l}\text { Temp. gas H2 } \\
\text { In }\end{array}$ & $\begin{array}{l}\text { K Adam } \\
4018\end{array}$ & Ch 01 & - \\
\hline 3 & $\begin{array}{l}\text { Temper } \\
\text { atur } \\
(\mathrm{Tc} 3)\end{array}$ & $\begin{array}{l}\text { Thermocouple } \\
\text { (Tipe-K) }\end{array}$ & $\begin{array}{l}\text { Temp. gas H2 } \\
\text { Out. }\end{array}$ & $\begin{array}{l}\text { K Adam } \\
4018\end{array}$ & Ch 02 & - \\
\hline 4 & $\begin{array}{l}\text { Temper } \\
\text { atur } \\
(\mathrm{Tc} 4)\end{array}$ & $\begin{array}{l}\text { Thermocouple } \\
\text { (Tipe-K) }\end{array}$ & $\begin{array}{l}\text { Temp. } \\
\text { air pendingin } \\
\text { In }\end{array}$ & $\begin{array}{l}\text { K Adam } \\
4018\end{array}$ & Ch 03 & - \\
\hline 5 & $\begin{array}{l}\text { Temper } \\
\text { atur } \\
\text { (Tc5) }\end{array}$ & $\begin{array}{l}\text { Thermocouple } \\
\text { (Tipe-K) }\end{array}$ & $\begin{array}{l}\text { Temp. } \\
\text { air pendingin } \\
\text { Out }\end{array}$ & $\begin{array}{l}\text { K Adam } \\
4018\end{array}$ & Ch 04 & - \\
\hline 6 & $\begin{array}{l}\text { Teganga } \\
\mathrm{n}(\mathrm{v})\end{array}$ & $\begin{array}{l}\text { Tegangan } \\
\text { Autotrafo } \\
\text { In: } 0-48 \mathrm{~V} \\
\text { Out: } 4-20 \mathrm{~mA}\end{array}$ & $\begin{array}{l}\text { Tegangan } \\
\text { heater } \\
\text { Tungku }\end{array}$ & $\begin{array}{l}\text { Adam } \\
4017\end{array}$ & Ch 00 & $\begin{array}{l}220 \\
\text { VAC }\end{array}$ \\
\hline
\end{tabular}

\begin{tabular}{|c|c|c|c|c|c|c|}
\hline 7 & $\begin{array}{l}\text { Arus } \\
\text { ( I1 ) }\end{array}$ & $\begin{array}{l}\text { AC } 3 \text { fasa (R) } \\
\text { In: } 0-1050 \mathrm{~A} \\
\text { Out: } 4-20 \mathrm{~mA}\end{array}$ & $\begin{array}{l}\text { Arus Heater } \\
\mathrm{R} \text { tungku }\end{array}$ & $\begin{array}{l}\text { Adam } \\
4017\end{array}$ & Ch 01 & $\begin{array}{l}220 \\
\text { VAC }\end{array}$ \\
\hline 8 & $\begin{array}{l}\text { Arus } \\
\text { ( I2 ) }\end{array}$ & $\begin{array}{l}\text { AC } 3 \text { fasa (S) } \\
\text { In: } 0-1050 \mathrm{~A} \\
\text { Out: } 4-20 \mathrm{~mA}\end{array}$ & $\begin{array}{l}\text { Arus Heater S } \\
\text { tungku }\end{array}$ & $\begin{array}{l}\text { Adam } \\
4017\end{array}$ & Ch 02 & $\begin{array}{l}220 \\
\text { VAC }\end{array}$ \\
\hline 9 & $\begin{array}{l}\text { Arus } \\
\text { ( I3) }\end{array}$ & $\begin{array}{l}\text { AC } 3 \text { fasa }(\mathrm{T}) \\
\text { In: } 0-1050 \mathrm{~A} \\
\text { Out: } 4-20 \mathrm{~mA}\end{array}$ & $\begin{array}{l}\text { Arus Heater } \\
\mathrm{T} \text { tungku }\end{array}$ & $\begin{array}{l}\text { Adam } \\
4017\end{array}$ & Ch 03 & $\begin{array}{l}220 \\
\text { VAC }\end{array}$ \\
\hline 10 & $\begin{array}{l}\text { Tekanan } \\
\text { (P1) }\end{array}$ & $\begin{array}{l}\text { Tekanan gas } \\
\text { (FESTO ) } \\
\text { In:0-2 bar (G) } \\
\text { Out:0,1-10 V }\end{array}$ & $\begin{array}{l}\text { Tekanan } \\
\text { masuk gas H2 }\end{array}$ & $\begin{array}{l}\text { Adam } \\
4017\end{array}$ & Ch 04 & $\begin{array}{l}14-30 \\
\text { VDC }\end{array}$ \\
\hline 11 & $\begin{array}{l}\text { Tekanan } \\
\text { (P2) }\end{array}$ & $\begin{array}{l}\text { Tekanan gas } \\
\text { (FESTO ) } \\
\text { In:0-2 bar (G) } \\
\text { Out:0,1-10 V }\end{array}$ & $\begin{array}{l}\text { Tekanan } \\
\text { keluar gas } \\
\text { H2 }\end{array}$ & $\begin{array}{l}\text { Adam } \\
4017\end{array}$ & Ch 05 & $\begin{array}{l}14-30 \\
\text { VDC }\end{array}$ \\
\hline 12 & $\begin{array}{l}\text { Flow } \\
\text { H2 } \\
\text { (Q1) }\end{array}$ & $\begin{array}{l}\text { Flow meter } \\
\text { (SIERRA) } \\
\text { In:0-50 SLPM } \\
\text { Out: } 0-5 \mathrm{~V} \\
\end{array}$ & $\begin{array}{l}\text { Flow input } \\
\text { gas H2 }\end{array}$ & $\begin{array}{l}\text { Adam } \\
4017\end{array}$ & Ch 06 & $\begin{array}{l}14-30 \\
\text { VDC }\end{array}$ \\
\hline 13 & $\begin{array}{l}\text { Flowr } \\
\text { H2 } \\
\text { (Q2) }\end{array}$ & $\begin{array}{l}\text { Flow meter } \\
\text { (FLOWSTREA } \\
\mathrm{M}) \\
\text { In:0-50 SLPM } \\
\text { Out: } 0 \text { - 5 V }\end{array}$ & $\begin{array}{l}\text { Flow output } \\
\text { gas H2 }\end{array}$ & $\begin{array}{l}\text { Adam } \\
4017\end{array}$ & Ch 07 & $\begin{array}{l}14-30 \\
\text { VDC }\end{array}$ \\
\hline 14 & $\begin{array}{l}\text { \% H2 di } \\
\text { Chambe } \\
\text { r }\end{array}$ & $\begin{array}{l}\text { LEL } \\
\text { In: } 0-75 \% \\
\text { Out : } 0-10 \mathrm{~V}\end{array}$ & $\begin{array}{l}\text { Kadar/ } \\
\text { prosentase } \\
\text { Gas H2 }\end{array}$ & $\begin{array}{l}\text { Adam } \\
4018\end{array}$ & Ch 06 & $\begin{array}{l}14-30 \\
\text { VDC }\end{array}$ \\
\hline
\end{tabular}

\subsection{Instalasi Sistem Akuisisi Data}

Instalasi sistem akusisi data dimulai dengan melakukan pembuatan wiring diagram dari sistem akusisi data yang diperlihatkan pada Gambar 8

Penempatan sistem akusisi data pada panel kendali sinter memanfaatkan ruang yang telah disediakan oleh pabrikan untuk pengembangan. Ruang panel dan sistem akusisi data setelah selesai di instalasi diperlihatkan pada Gambar 10.

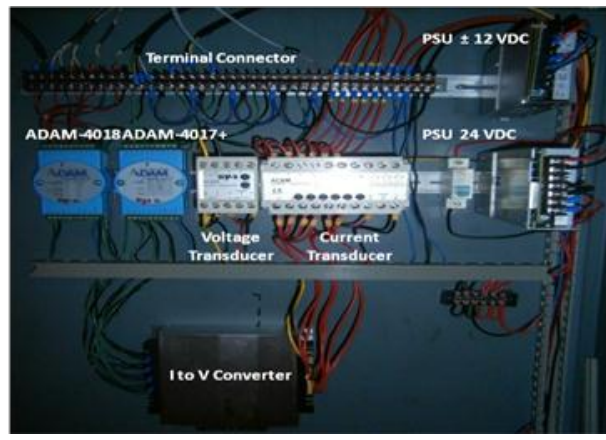

Gambar 10. Instalasi Sistem Akusisi Data pada Panel kendali

Tahapan berikutnya setelah selesai instalasi system, dilakukan pengujian komunikasi antara PC host kontrol dengan modul akusisi data. Pengujian dilakukan dengan menggunakan utilitas yang di sediakan Advantech. Pengujian sekaligus seting tiap kanal input di perlihatkan pada Gambar 10.

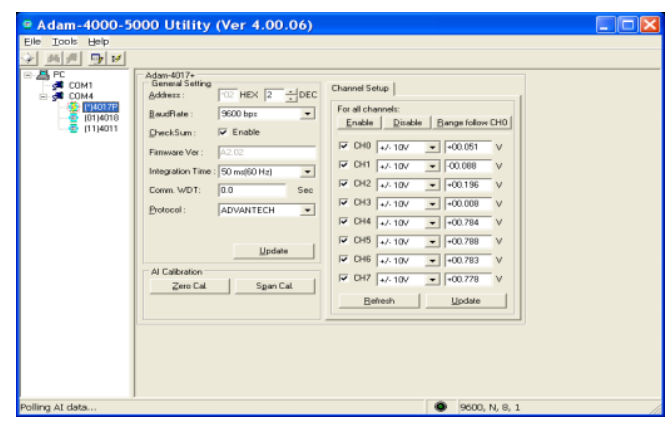




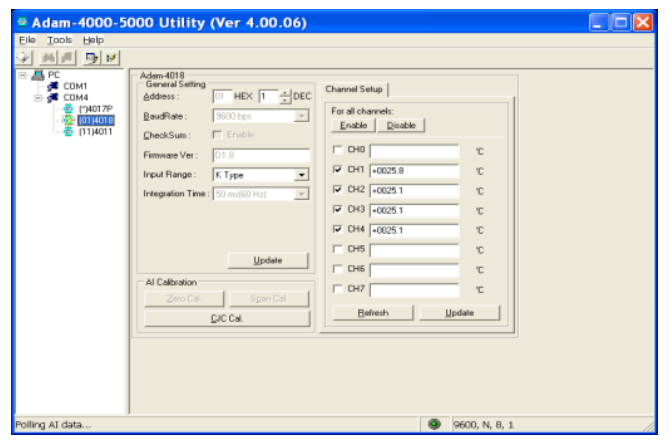

Gambar 11. Pengujian dan seting modul ADAM

\subsection{LabVIEW Kontrol Panel untuk Akusisi Data}

LabVIEW adalah bahasa pemrograman grafis yang menggunakan ikon untuk merepresentasikan suatu instruksi. Jika bahasa pemrograman text based mengksekusi instruksi sesuai dengan urutan yang ditulis, LabVIEW menggunakan metode dataflow programming dimana alur data melalui ikon akan menentukan urutan eksekusi dari setiap instruksi seperti yang ditunjukkan pada gambar 12.

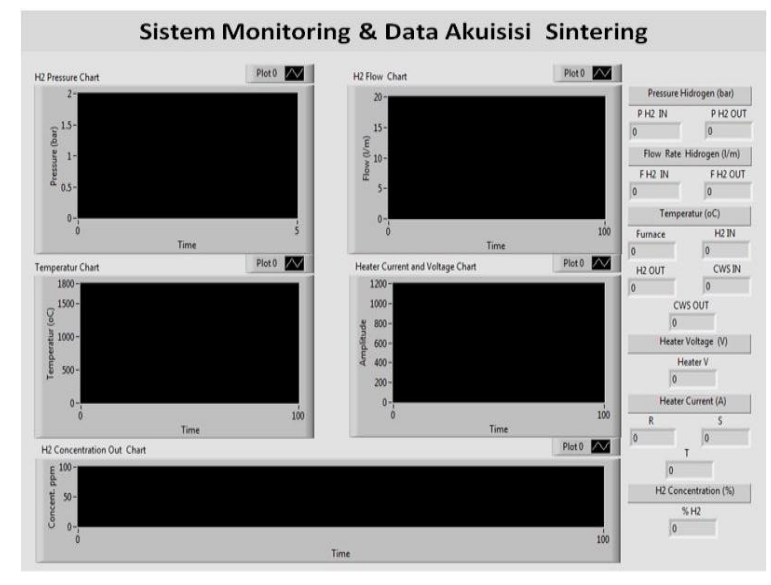

Gambar 12. Panel kontrol LabVIEW untuk Akusisi Data Proses Sintering

\section{Data Hasil Eksperimen Proses}

Akuisisi data variabel proses sintering dilakukan dengan parameter proses sebagai berikut; laju kenaikan temperatur $250^{\circ} \mathrm{C} / \mathrm{jam}$, temperature puncak sintering $1700^{\circ} \mathrm{C}$, proses pendinginan berlangsung secara konvensional, dan gas atmosfir yang digunakan adalah nitrogen pada temperatur $0-600^{\circ} \mathrm{C}$ selanjutnya gas atmosfir proses digantikan oleh gas hidrogen hingga proses pendinginan mencapai temperatur $600^{\circ} \mathrm{C}$ setelah itu gas atmosfir kembali digantikan oleh gas nitrogen hingga tahapan proses sintering selesai dilakukan [5].
Akuisisi data dilakukan secara online selama satu siklus proses sintering. Seting waktu sampling yang digunakan adalah satu detik sehingga jumlah sampel data yang diperoleh sebanyak 73.324 data. Gambar 11 memperlihatkan data temperatur ruang dalam tungku sinter, temperatur input dan output gas nitrogen dan hidrogen serta temperatur input dan output air pendingin. Seperti yang diperlihatkan Gambar 11 fluktuasi yang terjadi pada data temperature gas nitrogen dan hidrogen serta temperature air pendingin diakibatkan oleh transisi proses pada saat penggantian gas atmosfir proses dalam ruang bakar tungku sinter pada temperatur diatas $580^{\circ} \mathrm{C}$, fluktuasi terjadi hingga ruang bakar dalam tungku terisi secara homogen oleh gas hidrogen atau sebaliknya pada proses penurunan temperatur

Gambar 13, memperlihatkan parameter arus dan tegangan pemanas (heater) selama proses sintering berlangsung. Pada gambar tersebut terlihat bahwa pada tahapan awal proses sintering terjadi fluktuasi arus dan tegangan heater, hal ini disebabkan sifat lembam dari tungku dimana pada saat awal proses pemanasan ruang tungku yang cukup besar (sekitar $2 \mathrm{~m}^{3}$ ) masih dalam keadaan dingin, walaupun demikian setelah seluruh ruang tungku mengalami pemanasan yang homogen maka arus dan tegangan heater kembali stabil sesuai dengan laju penasansan yang telah di seting. Dari data temperature hasil akuisisi yang diperoleh terlihat bahwa masih diperlukan pengendalian temperatur yang lebih baik pada awal proses sehingga fluktuasi yang terjadi dapat diminimalisir, hal ini menjadi tantangan tahapan berikutnya dalam pengendalian dan monitoring proses sintering.

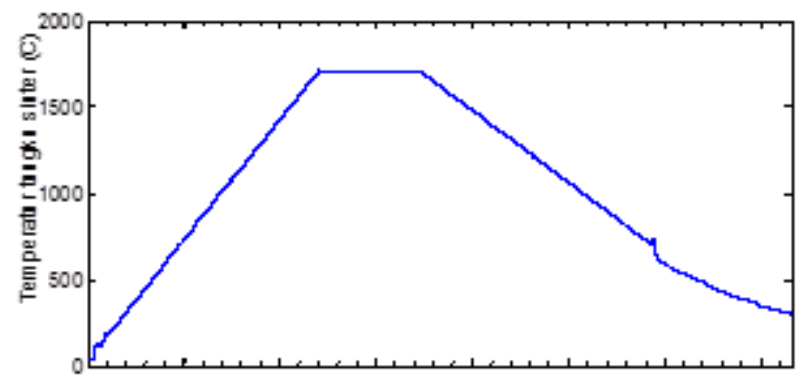



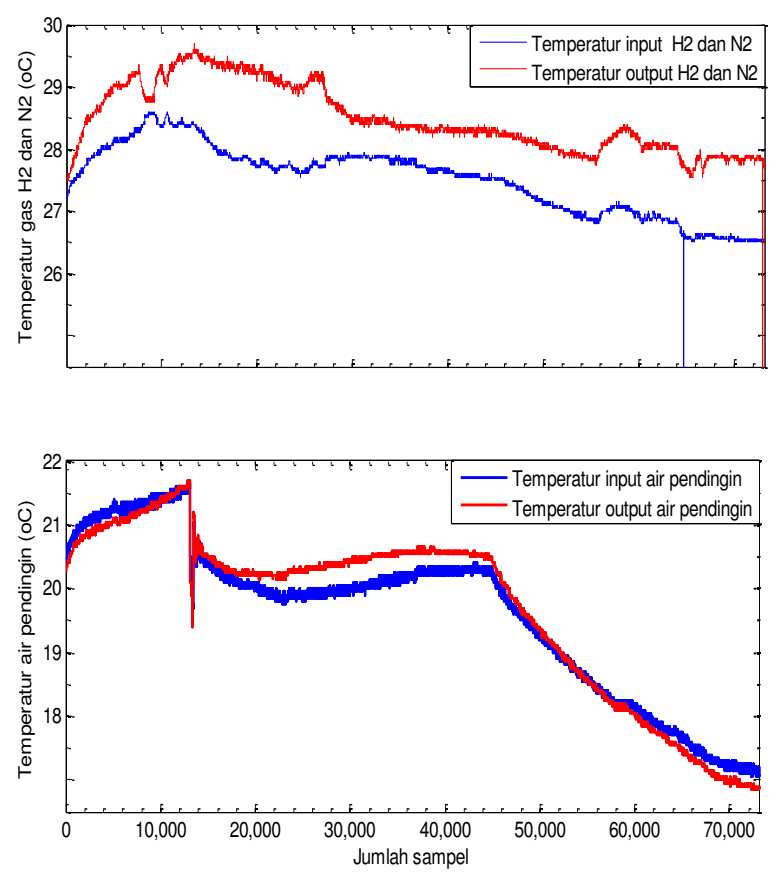

Gambar 13. Temperatur (a) Ruang Dalam Tungku Sinter, (b) I/O Gas Hidrogen dan Nitrogen, (c) I/O Air Pendingin
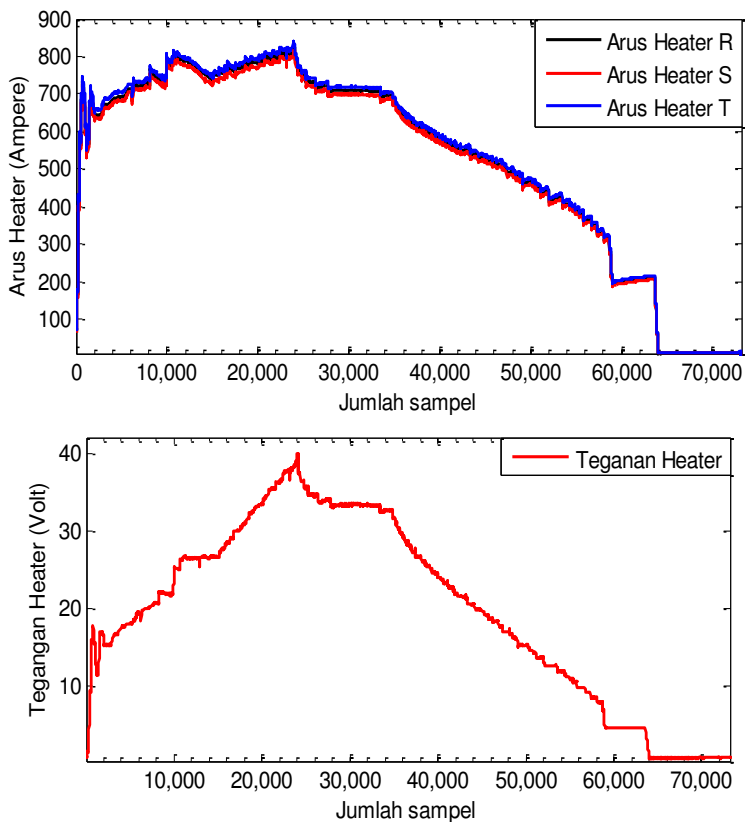

Gambar 14. (a) Arus Pemanas (heater, R-S-T), (b) Tegangan Pemanas

Seperti yang diperlihatkan Gambar 14, diatas bahwa terjadinya fluktuasi pada data tekanan dan laju alir gas nitrogen dan hidrogen yang diakibatkan oleh adanya transisi proses dari satu tahapan ke tahapan berikutnya dalam proses sintering serta reaksi fisika dan kimia yang menyertai transisi tersebut.
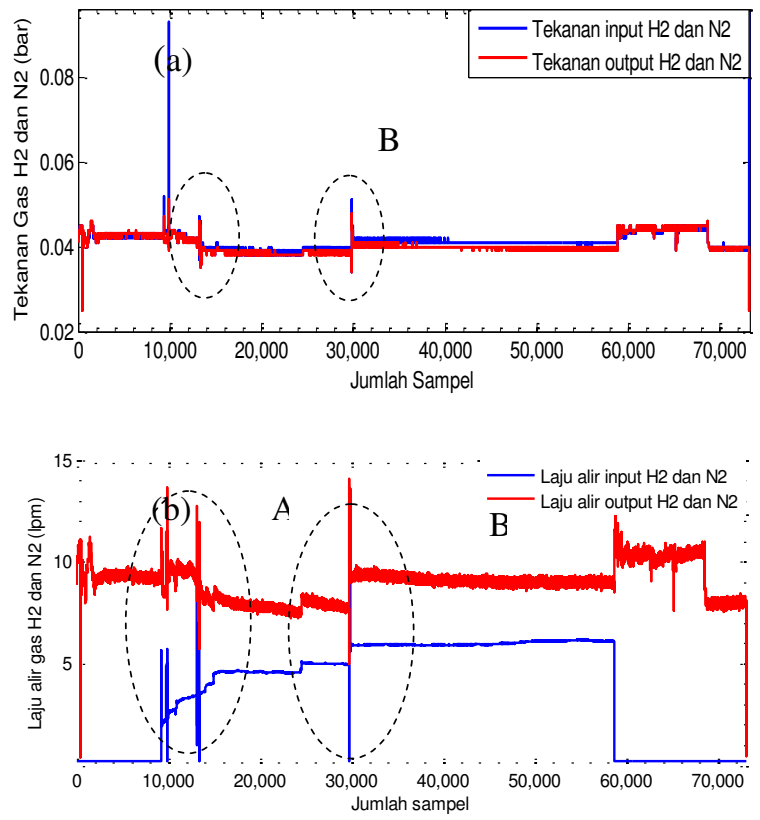

Gambar 15. (a) Tekanan I/O Nitrogen dan Hidrogen, (b) Laju Alir I/O Nitrogen dan Hidrogen

Bagian A pada Gambar 15, menggambarkan transisi penggunaan gas atmosfir proses dari nitrogen ke hidrogen pada temperatur diatas $580^{\circ} \mathrm{C}$, fluktuasi ini terjadi hingga seluruh ruang bakar tungku terisi homogen oleh gas hidrogen sedangkan bagian B merupakan transisi dari tahapan pemanasan ke tahapan penahanan (soaking time) pada temperatur puncak $1700^{\circ} \mathrm{C}$ selama sekitar 3 jam. Setelah transisi-transisi tersebut tekanan dan laju alir gas atmosfir proses kembali relatif stabil, walaupun demikian harus tetap diperhatikan agar fluktuasi yang terjadi tetap masih dalam rentang batas aman sehingga keselamatan proses sintering masih tetap terjaga.

\section{Kesimpulan Dan Saran}

Sistem data akuisisi (DAQ) untuk pengukuran variabel proses sintering telah dikembangkan dengan menggunakan modul data akusisi standar industri yang tersedia di pasaran. Eksperimen untuk akuisisi terhadap semua variabel proses dilakukan secara online ketika sintering berlangsung telah dilakukan.

Dari hasil eksperimen akuisisi data secara online terhadap proses sintering dalam mengukur sebelas variabel proses sinter, sistem akuisisi data yang dikembangkan memperlihatkan kinerja yang cukup baik, tidak terjadi kegagalan atau terhentinya akuisisi data yang di sebabkan oleh kerusakan sistem. Dari data runtun waktu sebelas variabel proses sintering yang diperoleh, sudah cukup memadai dan menggambarkan prilaku gas 
hidrogen dalam proses sintering. Data yang diperoleh akan digunakan sebagai bahan dalam memahami karakteristik proses sintering dengan membangun model berbasis jaringan saraf tiruan untuk memprediksi parameter keselamatan hidrogen pada penelitian berikutnya.

Data mentah hasil akuisisi masih memerlukan pemrosesan awal sebelum siap digunakan, untuk menganalisis adanya gangguan atau noise pada data sinyal hasil akuisisi. Oleh karena itu langkah selanjutnya adalah memproses data mentah dengan teknik pemrosean sinyal digital ataupun teknik lain misalnya data mining.

\section{Daftar Pustaka}

[1] M. Fischer. "Safety aspects of hydrogen combustion in hydrogen energy systems," International Journal of Hydrogen Energy, vol. 11, no. 9, pp. 593-601, 1986.

[2] H. Eichert and M. Fischer. "Combustion-related safety aspects of hydrogen in energy applications," International Journal of Hydrogen Energy, vol. 11, no. 2, pp. 117-124, 1986.

[3] I. Macintyre, a Tchouvelev, D. Hay, J. Wong, J. Grant, and P. Benard. "Canadian hydrogen safety program," International Journal of Hydrogen Energy, vol. 32, no. 13, pp. 2134-2143, September 2007.

[4] J. Luisaprea. Jul. "New standard on safety for hydrogen systems in spanish Keys for understanding and use," International Journal of Hydrogen Energy, vol. 33, no. 13, pp. 3526-3530, 2008.

[5] P. Lisboa. "Industrial use of safety-related artificial neural networks". 2001.

[6] P. Kadlec, B. Gabrys, and S. Strandt. "Data-driven Soft Sensors in the process industry," Computers and Chemical Engineering, vol. 33, no. 4, pp. 795814. Apr. 2009.

[7] S. Jassar, Z. Liao, and L. Zhao. "A recurrent neuro-fuzzy system and its application in inferential sensing," Applied Soft Computing, vol. 11, no. 3, pp. 2935-2945. Apr. 2011.

[8] M. Oliveira and R. Schirru. "Applying particle swarm optimization algorithm for tuning a neurofuzzy inference system for sensor monitoring," Progress in Nuclear Energy, vol. 51, no. 1, pp. 177-183. January 2009.

[9] S. A Kalogirou. "Artificial intelligence for the modeling and control of combustion processes: a review," Progress in Energy and Combustion Science, vol. 29, no. 6, pp. 515-566, Jan. 2003.

[10] J. Chandok, I. Kar, and S. Tuli. "Estimation of furnace exit gas temperature (FEGT) using optimized radial basis and back-propagation neural networks," Energy Conversion and Management, vol. 49, no. 8, pp. 1989-1998. Aug. 2008.
[11] T. Hong-wei, C. Jian-yuan, and W. Shi-dong. "The Effective Application of BP Neural Networks Prediction Model for Gas Content in Binchang Mining," in Computational Intelligence and Software Engineering, CiSE 2009, no. 1, pp. $1-4$. 